\title{
IMPACT OF DRAINAGE ON HEAVY METAL POLLUTION OF SOILS AND LAND USAGE REGULATION
}

\author{
Inna Davydova ${ }^{1}$, Yury Mazhayskiy ${ }^{2}$, Evgeny Davydov ${ }^{3}$, Tatiana Guseva ${ }^{4}$ \\ ${ }^{1,2}$ Ryazan State University, Russia; ${ }^{3}$ Dubna State University, Russia; \\ ${ }^{4}$ Ryazan State Medical University, Russia \\ i.davidova@rsu.edu.ru,mail@mntc.pro,davydov@theor.jinr.ru,guseva.tm@yandex.ru
}

\begin{abstract}
Lands of industrial regions are often subjected to long-term contamination with heavy metals such as cadmium, zinc, lead, copper etc. Heavy metals circulate mostly due to water flows, and in the areas with humid (micro) climate, the heavy metal pollution propagates from sources with increased intensity because of acidic environment and soil water logging. We established that natural or artificial drainage effectively increases the washout of heavy metal pollutants due to subsurface and groundwater flows. As a result, soils of drained lands are less subjected to long-term contamination by heavy metals. We introduce the eco-centric approach to land regulation policy in industrialized regions, which stimulates the development of drainage systems and the accurate usage of lands with high natural drainage level. The approach accounts for cost-benefit balance and allows preventing systemic environmental problems.
\end{abstract}

Keywords: soil pollution, drainage and melioration, environmental risk.

\section{Introduction}

The problem of optimizing the quality of the environment requires constant attention due to the continuing negative impact on ecosystems and human health. The solution of this problem is related to the consideration of environmental risks caused by legal, economic, hygienic and environmentalgeochemical factors. The complexity of the task requires improvement of the methodological approaches to its solution. The aim of our research is to improve the methods for assessing the environmental risk associated with heavy metal contamination of soils in the long-term transport of pollutants from sources of industrial emissions of metals. Such emissions are typical for many industrialized and densely populated regions, where there are enterprises of ferrous and non-ferrous metallurgy, fuel and energy industries, machine building and metal processing, oil refining and construction material production.

Generally, control over soil pollution is a state measure. For instance, according to the Russian Federation Government Decree No. 1316-r of July 8, 2015, cadmium (Cd), copper $(\mathrm{Cu})$, lead $(\mathrm{Pb})$ and zinc $(\mathrm{Zn})$ are included into the list of soil pollutants. Therefore, measures of state regulation in the field of environmental protection can be applied when soil is contaminated with these heavy metals, and legal prerequisites arise to take into account environmental risks associated with possible damage.

There are certain methodological difficulties in assessing environmental risks, since there are different approaches to determining the level of adverse effects of pollution on soils. The main methodological problem is the choice of a standard for its comparison with the actual concentration of pollutants in the soil. Most of the existing methodological approaches concern cases of local soil contamination. As a result, preference is given to such hygienic standards as the maximum permissible concentration (threshold limit value, TLV) or the estimated permissible concentration (estimated threshold limit value, ETLV) of a polluting chemical.

These standards have higher values than clarks [5] (numbers expressing the average content of chemical elements in the earth crust, hydrosphere, etc., with respect to the total mass of this system), background values for individual soil groups, regional background values [1], as well as ecological standards based on the landscape approach [6].

We insist that for extensive land contamination in the long-term transport of pollutants, a methodical approach using the hygienic standards of TLV or ETLV pollutant as reference standards is unacceptable for a number of reasons. First, large-scale contamination of soils with heavy metals does not have high quantitative indices. For instance, the State Report "On the State and Protection of the Environment of the Russian Federation in 2015" [3], estimates the degree of danger effects on human health due to soil contamination by a complex of heavy metals based on the total contamination index $Z_{f}$ (with backgrounds taken into account) and (or ) $Z_{c}$ (including clarks). It declares that in the surveyed regions, including the Center of Russia, the permissible category of soil contamination with heavy 
metals prevails, despite the obvious pollution of the environment in the long-term transport of heavy metals and the variety of methods for their migration in landscapes, leading to an environmentaltoxicological hazard for all living organisms. Such discrepancy appears when the actual pollutant content in the soil is higher than the clark and (or) background, but below TLV or ETLV, so the amount of damage caused to soils due to heavy metal contamination is often left undetermined. Consequently, the assessment of environmental risk becomes meaningless within that approach.

Secondly, it is necessary to note the problem of soil quality monitoring, since the initial pollution criteria, depending on the size of the established damage, are equated to zero if TLV or ETLV has not been exceeded. In such a case, no informative basis is created to determine the amount of accumulated harm due to continuing pollution, although this is required by the legislation, e.g., in Russian Federation[6]. In addition, the perpetrators of local soil contamination, supplementing the result of long-range transport of pollutants, remain undetected. Even worse is that the economic assessment of negative changes in the quality of agricultural products and water resources of the agricultural landscape is left entirely undetermined, if the background level of soil contamination is acceptable (less than TLV and ETLV). Thirdly, for some soils like peat bog soils or alluvial soils the evaluation criteria for heavy metal contamination are absent, which can be explained by excessive generalizations in the regulation of pollution.

In addition to the listed general methodological issues in the field of environmental risk assessment, there are obvious gaps in the establishment of insight factors. For example, if the humid zone soils are polluted with heavy metals, the natural or artificial drainage of the territory will be a factor reducing the environmental risk. For instance, terrain relief affects the soils moistening, and, therefore, the removal of heavy metals from them. The functioning drainage system acts in the same way, since the pollutants will be washed out with drainage runoff. Obviously, the ecological services of the relief and/or drainage system should be taken into account to adjust the risk in situ, for example, when assessing the risks for contaminated drained wetland or floodplain soils.

\section{Materials and methods}

Earlier we performed a soil survey in which we studied the soil contamination by heavy metals cadmium $(\mathrm{Cd})$, copper $(\mathrm{Cu})$, lead $(\mathrm{Pb})$, zinc $(\mathrm{Zn}),-$ as well as determination of $\mathrm{pH}$ and humus content [2]. In this paper, based on the previous experimental data, we calculate the values of the polyelement soil contamination indicator $\left(H_{C}\right)$ and introduce a novel approach to land use regulation, regarding this indicator. The indicator $H_{C}$ is inherently the sum of pollutant concentration coefficients and allows calculating the damage caused to soils due to chemical contamination. It is similar to the abovementioned total index of complex pollution $Z_{f}$ (with backgrounds taken into account) and (or) $Z_{c}$ (including clarks). This follows from the fact that during $H_{C}$ calculation the ratio of actual concentrations of pollutants in the soil to the background values is summarized in the same way. Thus, the indicator $H_{C}$ can be used to determine the level of land pollution by chemicals.

We propose to compare the $H_{C}$ values obtained by different approaches for better evaluation of environmental risks:

$$
\begin{gathered}
\text { a) } H_{C}=\sum_{j} \frac{C_{j}}{C_{r b, j}}, \text { b) } H_{C}=\sum_{j} \frac{C_{j}}{C_{g b, j}}, \text { c) } H_{C}=\sum_{j} \frac{C_{j}}{C_{\text {clarcke }, j}}, \\
\text { d) } H_{C}=\sum_{j} \frac{C_{j}}{E T L V_{j}}, \text { e) } H_{C}=\sum_{j} \frac{C_{j}}{R E S_{j}},
\end{gathered}
$$

where $j$-enumerates pollutant species;

$C$ - actual pollutant content in soil, $\mathrm{mg} \cdot \mathrm{kg}^{-1}$;

$C_{r b}$ - regional background content of heavy metal in soil, $\mathrm{mg} \cdot \mathrm{kg}^{-1}$;

$C_{g b}$ - regional background content of heavy metal in soil, $\mathrm{mg} \cdot \mathrm{kg}^{-1}$;

$C_{\text {clarke }}$ - clark of a chemical element in the upper part of the continental crust, $\mathrm{mg} \cdot \mathrm{kg}^{-1}$;

$E T L V$ - estimated threshold limit values of heavy metals in soil, $\mathrm{mg} \cdot \mathrm{kg}^{-1}$;

$R E S$ - regional environmental standards for the content of heavy metals in soil, $\mathrm{mg} \cdot \mathrm{kg}^{-1}$; 
Next, we develop a new approach accounting the effect of drainage on the environmental risks. Firstly, a comparison of automorphic soils with their semi-hydromorphic zonal analogs was made to compare the contamination levels of these soils with heavy metals under conditions of different natural drainage of the territory. Secondly, a comparison was made between the levels of contamination by heavy metals of drained intrazonal soils (marsh peat soils, alluvial soils) with marsh analogues. Such a methodological approach helps substantiate the importance of environmental services of drainage meliorative systems in assessing the risk of soil and land contamination with heavy metals.

Usually, the choice of soil research objects for conducting comparative analysis is determined by the prevailing ecological and biochemical situation in the region. The ability of soils to self-cleaning from heavy metals can be characterized as average for sod-podzolic sandy and sandy loamy soils of the southern taiga, low for gray forest loamy soils of the forest-steppe, very low for peat soils in wetlands [3]. This circumstance is due to the genesis of soils: the higher the content of organic matter (humus, peat) and clay in soil, the greater the soil absorption capacity with respect to heavy metals. In addition, the $\mathrm{pH}$ of the medium in the soil is important: the lower the $\mathrm{pH}$, the less fixed in the soil heavy metals.

All these ecological and bioochemical factors were taken into account when choosing the following research objects: sod-podzolic soils, gray forest soils, peaty peat soils, alluvial soils. Analysis of soil contamination by gross forms of heavy metals - cadmium $(\mathrm{Cd})$, copper $(\mathrm{Cu})$, lead $(\mathrm{Pb})$, zinc $(\mathrm{Zn})$ - was performed on soil genetic horizons, taking into account the granulometric composition, humus content of peat, $\mathrm{pH}$ as factors responsible for soil self-cleaning. Finally, all soil objects were selected in such a way that the intensity of the long-range transport of pollutants was approximately the same [6].

We carried out the lysimetric experiment in order to assess the effect of the permissible level of heavy metal contamination (0.5 ETLV) of sod-podzolic sandy loam soils on the quality of crop production and the hydrochemical composition of the intrasoil runoff in conditions of drained agrolandscape [4]. The artificial level of soil contamination was 0.5 ETLV for each heavy metal, namely: $\mathrm{Cd}-0.25 \mathrm{mg} \cdot \mathrm{kg}^{-1} ; \mathrm{Cu}-16.5 \mathrm{mg} \cdot \mathrm{kg}^{-1} ; \mathrm{Pb}-16.0 \mathrm{mg} \cdot \mathrm{kg}^{-1} ; \mathrm{Zn}-27.5 \mathrm{mg} \cdot \mathrm{kg}^{-1}$. The amount of heavy metals $(Q)$ in the contaminated $\left(Q_{p}\right)$ and background $\left(Q_{b}\right)$ variants of the experiment was controlled, including: 1 - the initial amount of heavy metals in the soil $\left(Q_{0}\right) ; 2$ - the amount of heavy metals entering the soil with atmospheric precipitation during long-range transport $\left(Q_{a}\right) ; 3$ - the amount of heavy metals released from the soil by a crop yield $\left(Q_{h}\right) ; 4$ - the amount of heavy metals carried by lysimetric waters beyond the root-soil layer $\left(Q_{w}\right)$. The established concentrations of heavy metals in soil, plants, atmospheric precipitation, lysimetric waters were recalculated in grams per hectare $\left(\mathrm{g} \cdot \mathrm{ha} \mathrm{H}^{-1}\right)$.

To assess the response of the soil to contamination [6], the following were determined: $1-$ selfcleaning coefficient of soil when heavy metals are carried out by harvest $\left(K_{h}=\left[Q_{h}{ }^{p}-Q_{h}^{b}\right] / Q_{h}^{b}\right) ; 2$ - coefficient of soil self-cleaning when carrying heavy metals with lysimetric waters $K_{w}=\left[Q_{w}{ }^{p}-Q_{w}{ }^{b}\right] / Q_{h}{ }^{b}$ All data are presented in Table 1.

Self-cleaning of sod-podzolic sandy loam soil from heavy metals in drained agricultural landscape

\begin{tabular}{|c|c|c|c|c|c|c|c|}
\hline \multirow{2}{*}{\multicolumn{2}{|c|}{$\begin{array}{c}\text { Detection } \\
\text { of }\end{array}$}} & $Q_{0}$ & $Q_{a}$ & $Q_{h}$ & $Q_{w}$ & \multirow[t]{2}{*}{$K_{h}$} & \multirow[t]{2}{*}{$K_{w}$} \\
\hline & & \multicolumn{4}{|c|}{$\mathrm{g} / \mathrm{ha}$} & & \\
\hline \multirow[t]{2}{*}{$\mathrm{Cd}$} & $Q^{p}$ & 500.0 & 8.0 & 1.2 & 0.001 & \multirow[t]{2}{*}{0.2} & \multirow[t]{2}{*}{0.0} \\
\hline & $Q^{b}$ & 60.0 & 8.0 & 1.0 & 0.001 & & \\
\hline \multirow[t]{2}{*}{$\mathrm{Cu}$} & $Q^{p}$ & 33000.0 & 4.0 & 28.0 & 2.8 & \multirow[t]{2}{*}{1.0} & \multirow[t]{2}{*}{0.0} \\
\hline & $Q^{b}$ & 5200.0 & 4.0 & 14.0 & 2.8 & & \\
\hline \multirow[t]{2}{*}{$\mathrm{Pb}$} & $Q^{p}$ & 32000.0 & 14.0 & 10.0 & 2.0 & \multirow[t]{2}{*}{0.0} & \multirow[t]{2}{*}{0.3} \\
\hline & $Q^{b}$ & 7200.0 & 14.0 & 10.0 & 1.6 & & \\
\hline \multirow[t]{2}{*}{$\mathrm{Zn}$} & $Q^{p}$ & 55000.0 & 6.0 & 318.0 & 6.2 & \multirow[t]{2}{*}{1.5} & \multirow[t]{2}{*}{0.7} \\
\hline & $Q^{b}$ & 26200.0 & 6.0 & 126.0 & 2.2 & & \\
\hline
\end{tabular}


Impact of natural drainage on integral indicator of polyelement pollution $\left(H_{C}\right)$

\begin{tabular}{|c|c|c|c|c|c|c|c|c|}
\hline \multirow{2}{*}{$\begin{array}{l}\text { Soil position } \\
\text { in the } \\
\text { landscape; } \\
\text { moisture } \\
\text { conditions }\end{array}$} & \multirow[t]{2}{*}{ Soil name } & \multirow{2}{*}{$\begin{array}{l}\text { Pedogenic } \\
\text { horizon; } \\
\text { depth, cm }\end{array}$} & \multirow{2}{*}{$\begin{array}{l}\text { Particle- } \\
\text { size } \\
\text { distribu- } \\
\text { tion }\end{array}$} & \multicolumn{5}{|c|}{$\begin{array}{c}H_{C} \text { values for a)-e) } \\
\text { calculation methods (1) }\end{array}$} \\
\hline & & & & $\mathrm{a}$ & $\mathrm{b}$ & $\mathrm{c}$ & d & $\mathrm{e}$ \\
\hline \multirow{2}{*}{$\begin{array}{l}\text { Dry sand } \\
\text { dune }\end{array}$} & \multirow{2}{*}{$\begin{array}{l}\text { Sod-podzolic } \\
\text { poorly } \\
\text { differentiated } \\
\text { sandy soil }\end{array}$} & $\mathrm{A}_{1}, 5-10$ & Sandy & 1.6 & 4.8 & 2.4 & 0.4 & 1.6 \\
\hline & & $\mathrm{B}_{1}, 30-35$ & Sandy & 1.6 & 4.2 & 2.7 & 0.3 & 1.4 \\
\hline \multirow[t]{2}{*}{$\begin{array}{l}\text { Moist } \\
\text { lowland }\end{array}$} & \multirow{2}{*}{$\begin{array}{l}\text { Sod-podzolic } \\
\text { with ortzand } \\
\text { layer sandy } \\
\text { soil gleyed by } \\
\text { subterranean } \\
\text { water }\end{array}$} & $\mathrm{A}_{1 \mathrm{~g}}, 5-10$ & $\begin{array}{l}\text { Fine } \\
\text { sandy }\end{array}$ & 2.0 & 5.9 & 3.0 & 0.4 & 1.4 \\
\hline & & $\mathrm{B}_{\mathrm{g}}, 35-45$ & Sandy & 1.7 & 5.4 & 2.8 & 0.3 & 1.5 \\
\hline \multirow{2}{*}{$\begin{array}{l}\text { River terrace } \\
\text { steep slope }\end{array}$} & \multirow{2}{*}{$\begin{array}{l}\text { Gray forest } \\
\text { loamy } \\
\text { mastered soil }\end{array}$} & $A_{1}, 10-20$ & Loamy & 3.5 & 3.1 & 4.4 & 0.9 & 2.0 \\
\hline & & $\begin{array}{c}\mathrm{A}_{2} \mathrm{~B}, 36- \\
46\end{array}$ & Loamy & 2.9 & 2.6 & 4.1 & 0.6 & 1.8 \\
\hline \multirow{4}{*}{$\begin{array}{l}\text { Periodically } \\
\text { waterlogged } \\
\text { shallow } \\
\text { depression } \\
\text { ("steppe } \\
\text { saucer") }\end{array}$} & \multirow{4}{*}{$\begin{array}{l}\text { Sod-podzolic } \\
\text { loamy } \\
\text { mastered soil } \\
\text { gleyed by } \\
\text { perched } \\
\text { ground water }\end{array}$} & $A_{p}, 10-15$ & Loamy & 4.6 & 5.5 & 5.4 & 1.3 & 2.5 \\
\hline & & $\begin{array}{l}\mathrm{A}_{2 \mathrm{~g}}, 50- \\
55\end{array}$ & $\begin{array}{l}\text { Silty } \\
\text { loam }\end{array}$ & 4.4 & 5.4 & 5.8 & 1.2 & 2.7 \\
\hline & & $\mathrm{B}_{1 \mathrm{~g}}, 80-90$ & Loamy & 4.6 & 5.8 & 6.0 & 1.1 & 2.5 \\
\hline & & $\begin{array}{l}\mathrm{B}_{2 \mathrm{t}}, 100- \\
105\end{array}$ & $\begin{array}{l}\text { Clay } \\
\text { loamy }\end{array}$ & 3.2 & 3.8 & 3.4 & 0.8 & 1.9 \\
\hline
\end{tabular}

Table 3

Impact of artificial drainage on heavy metal total content in peat bog soils and floodplain soils and integral indicator of polyelement pollution $\left(H_{C}\right)$

\begin{tabular}{|c|c|c|c|c|c|c|c|}
\hline \multirow{2}{*}{$\begin{array}{l}\text { Soil position in the } \\
\text { landscape; moisture } \\
\text { conditions; economic } \\
\text { use }\end{array}$} & \multirow[t]{2}{*}{ Soil name } & \multirow[t]{2}{*}{$\begin{array}{l}\text { Pedogenic } \\
\text { horizon; } \\
\text { depth, cm }\end{array}$} & \multirow{2}{*}{$\begin{array}{l}\text { Particle- } \\
\text { size } \\
\text { distri- } \\
\text { bution } \\
\end{array}$} & \multicolumn{4}{|c|}{$\begin{array}{l}H_{C} \text { values for a)-d) } \\
\text { calculation methods } \\
\text { (1) }\end{array}$} \\
\hline & & & & $\mathrm{a}$ & $\mathrm{b}$ & $\mathrm{c}$ & $\mathrm{d}$ \\
\hline $\begin{array}{l}\text { Drained high bog; } \\
\text { peat-land }\end{array}$ & Swamp peat & $\mathrm{T}, 0-20$ & - & 2.5 & 3.7 & - & 1.7 \\
\hline \multirow{2}{*}{$\begin{array}{l}\text { Drained lowland } \\
\text { bog; meadow and } \\
\text { pasture }\end{array}$} & \multirow{2}{*}{$\begin{array}{l}\text { lowland bog } \\
\text { humus-gley } \\
\text { mastered soil }\end{array}$} & $1_{\pi}, 10-15$ & - & 2.8 & 3.4 & - & 2.2 \\
\hline & & $\mathrm{G}, 30-40$ & Sandy & 2.6 & 3.7 & 1.2 & 1.7 \\
\hline $\begin{array}{l}\text { Drained lowland } \\
\text { bog; secondary } \\
\text { bogging; forestry }\end{array}$ & $\begin{array}{l}\text { Lowland bog } \\
\text { peaty gley } \\
\text { soil }\end{array}$ & $\mathrm{T}, 0-5$ & - & 7.9 & 5.1 & - & 2.1 \\
\hline \multirow{2}{*}{$\begin{array}{l}\text { Drained bar } \\
\text { floodland; meadow } \\
\text { and pasture }\end{array}$} & \multirow{2}{*}{$\begin{array}{l}\text { Sod alluvial } \\
\text { light loamy } \\
\text { sour soil }\end{array}$} & $\mathrm{A}_{1}, 10-15$ & $\begin{array}{l}\text { Silty } \\
\text { loam }\end{array}$ & 4.4 & 6.1 & 1.0 & 1.7 \\
\hline & & $\mathrm{B}_{1}, 30-35$ & Loamy & 4.9 & 5.0 & 1.3 & - \\
\hline \multirow{2}{*}{$\begin{array}{l}\text { Drained ox-bow } \\
\text { marsh; meadow and } \\
\text { pasture }\end{array}$} & \multirow{2}{*}{$\begin{array}{l}\text { Alluvial } \\
\text { meadow- } \\
\text { marsh silty } \\
\text { soil }\end{array}$} & $A_{g}, 5-10$ & Silty & $\begin{array}{c}11 . \\
8\end{array}$ & $\begin{array}{c}18 . \\
7\end{array}$ & 2.7 & 4.5 \\
\hline & & $\mathrm{B}_{\mathrm{g}}, 20-30$ & Silty & 6.1 & 9.7 & 1.3 & 2.7 \\
\hline
\end{tabular}

\section{Results and discussion}

The obtained indicator $H_{C}$ values are presented in Tab. 2 and Tab. 3. First, let us note the low values of the polyelement contamination indicator in all the investigated soils. In addition, the values 
of this indicator decrease from the upper soil horizons to the lower ones. The established patterns are similar for all $H_{C}$ calculation methods and expose the contribution of the main contamination factor: long-range transport of pollutants with air currents. However, the local soil formation conditions can have an effect on the local variability of the $H_{C}$ indicator and, thus, of environmental risk.

It was previously established that in the case of long-distance transport of pollutants, the granulometric composition of the soil has the greatest effect on the accumulation of heavy metals in the soils of the region; the humus content and the $\mathrm{pH}$ of the soil are less important [1]. Now more attention was paid to the study of natural and artificial drainage of soils as a local factor of environmental risk in the situation of extensive contamination of lands with heavy metals after their dispersion in the atmosphere and long-range transport from emission sources. The working hypothesis was that, under otherwise equal conditions (soil size distribution, soil $\mathrm{pH}$, humus content, peat, land usage type, etc.), the strengthening or weakening of environmental risk caused by soil contamination with heavy metals will depend mostly on the degree of soil hydromorphism.

Obviously, in the automorphic conditions of soil moistening with atmospheric precipitation, the processes of natural soil purification from heavy metals will proceed more actively than with mixed atmospheric-soil or mainly ground moistening. This pattern is associated with a multidirectional flow of water in the soil: under automorphic conditions, the descending current of water prevails and, consequently, the washing out of heavy metals; And in semi-hydromorphic or hydromorphic conditions, the rise of soil-groundwater to the earth's surface will facilitate the return of pollutants. The increase in soil hydromorphism is associated with the position of the soil in the landscape, which depends on the meso- or microrelief. On the elevations of the relief (hillocks, dunes, river or lake terraces, etc.), automorphic soil moistening conditions are usually formed, and semi-hydromorphic or hydromorphic conditions of soil moistening arise in depressions (lowlands, valleys, foot slopes, etc.). Consequently, the soils formed on positive forms of relief will be more pure in conditions of longrange transport of heavy metals than soils confined to negative forms of relief, other things being equal. It is obvious that this regularity is strengthened in the situation of geochemical conjugation of soils caused by their belonging to the same soil catene. In this case, the soils of autonomous landscape positions will serve as a source of secondary contamination by heavy metals of soils of heterogeneous positions, which is caused by surface or soil-ground runoff of water.

Artificial drainage of the territory, or drainage land reclamation, provides a similar effect. Heavy metals are removed from the soil with a drainage, which leads to a reduction in pollution and corresponding environmental risks. Therefore, when assessing the environmental risk caused by heavy soil contamination of soils, it is necessary to take into account the state of the drainage system on reclaimed lands exposed to long-range transport of these pollutants.

The working hypothesis considered was tested in the study of a number of soil objects. The results of the studies presented in Tables 2 and 3 confirm its validity. For instance, from Tab. 2. we see that naturally drained sod-podzolic sandy soil in terms of the polyelement pollution indicator $H_{C}$ is cleaner than its semihydromorph analogue, sod-podzolic soil-gley ortsand sandy soil. This is a result of pollutants leaching due to vertical outflow of water from sod-podzolic sandy soil, which was formed in automorphic conditions on a dry sand dune. In the humid lowland sod-podzolic soil-gley ortsand sandy soil is influenced not only by atmospheric, but also by ground moistening, therefore this soil is susceptible to secondary contamination by heavy metals from soil-groundwater. Similarly, gray forest developed middle loamy soil is characterized by lower values of $H_{C}$ than sod-podzolic surface-gleyed medium loamy ground. The reasons for the differences are due to their landscape positions: the first soil is located on the steep slope of the river terrace in automorphic humidification conditions, and the second one is situated in a periodically waterlogged deepening.

The effect of artificial drainage on the integral index of polyelement contamination $H_{C}$ can be found in Tab. 2; it almost coincides with the action of the positive form of relief. In the forest-marshy landscape of the natural zone of southern taiga, drained swamp peat soils (and upland and lowland soils) are characterized by low values of $H_{C}$. On the contrary, marsh lowland peaty-gley soil, which is subjected secondary swamping and, consequently, recontamination, has higher values of $H_{C}$.

In addition, we found that environmental risks due to soil contamination by heavy metals are generally diverse for different metals. It follows from Tab.1 that self-cleaning of soil due to the 
removal of pollutants by harvest decreases in the series $\mathrm{Zn}>\mathrm{Cu}>\mathrm{Cd}>\mathrm{Pb}$. Therefore, environmental risk associated with the receipt of heavy metals from contaminated soil in crop production and in water bodies with drainage runoff is higher for Zn contamination. On the other hand, environmental risk caused by the tendency of heavy metals accumulation in the soil of dried agrolandscape is higher for $\mathrm{Cd}, \mathrm{Cu}$ and $\mathrm{Pb}$ due to their low water-migration and translocative mobility.

Thus, we have established the correlation between land drainage and pollution of soil by heavy metals. Moreover, the type of soil itself appears to be a good indicator of the drainage level, because the moisture regime influences both the formation of soil, and the migration of heavy metals in the soil. This correlation should be embedded into the eco-centric land regulation policy in the industrialized regions. The paradigm of eco-centric policy for sustainable development [7] opposes the currently dominant economic growth paradigm [8] in order to prevent systemic environmental problems. Therefore, the free land market has to be constrained in order to stimulate the land usage with maximized environmental benefits. These benefits at large timescale will be inevitably converted into economic gains, as well. However, this timescale is usually beyond the planning horizon of typical investment projects, which makes it difficult to monetize the ecological entities and processes [9].

We propose to consider the presence of land drainage (artificial or natural) as an ecological benefit, which mitigates the risks for the overall region development strategy including diverse investment projects. Consequently, the land price regulation practice in the industrialized regions should target the following goals:

- stimulation of agricultural and/or residential usage of well-drained soils;

- development of drainage systems on lands with high levels of soil contamination by heavy metals.

In order to achieve these goals one should calculate high $H_{C}$ values for lands in the region. The possible way is to calculate the values for some "typical" lands, and then assign the values to other lands using some interpolation technique. The $H_{C}$ value calculated for the parcel can be treated as "high" (or "low") when it exceeds (or not) the average $H_{C}$ value throughout the region.

Then, the first objective can be implemented simply by transferring the lands with low $H_{C}$ values into the class restricted to mostly agricultural/residential/recreational usage.

The second goal can be achieved by discounting the cost of lands with high $H_{C}$ values, in case when the lands are used for agricultural purposes. The discount value should be equal to an appropriate cost of the drainage system implementation. This will motivate the customers and land users to promote drainage systems instead of abandoning the lands, which inevitably will be polluted with time. As a result, the soil contamination by heavy metals will be preserved below TLV, providing a sustainable ecosystem in the region. One of the simplest formulas accounting for the cost-benefit balance, which estimates the discount value per ha, may look like:

$$
D=\left(\frac{H_{C}}{\left\langle H_{C}\right\rangle}-1\right) \cdot\langle C\rangle
$$

where $D$-discount value, per ha;

$H_{C}$ - parcel polyelement soil contamination indicator;

$\left\langle H_{C}\right\rangle$ - average polyelement soil contamination indicator;

$\langle C\rangle$ - average cost of drainage system implementation, per ha.

Although the society will bear the costs of the discounting, the ecological benefits are quite manifest. Drainage improves the quality of soils and decreases their contamination level, which is especially important in the industrialized regions. The quality of soils should not be treated only as their fertility for the agricultural purposes. Soil is an essential part of the ecosystem, and the lands with soils of higher quality provide a more fertile environment suitable for diverse recreation activities. 


\section{Conclusions}

1. We propose to use a polyelement soil contamination indicator $H_{C}$, which is sensitive to long-term land pollutions by heavy metals in industrialized regions.

2. The $H_{C}$ value of land depends on the drainage capacity: the better is drainage (natural or artificial) the less is the level of contamination by heavy metals.

3. One can pursue the eco-centric policy by implementation of land regulation accounting for $H_{C}$ values of parcels.

4. Certain ecological benefits can be achieved by stimulation of drainage system development with the help of lands discounting by cost-benefit approach.

\section{References}

1. Мажайский Ю. А., Тобратов С. А., Дубенок Н. Н., Пожогин Ю. П. Агроэкология техногенно загрязненных ландшафтов (Agroecology of technogenically polluted landscapes). Смоленск: Маджента, 2003. 384 p. (In Russian).

2. Давыдова И. Ю. и др. Атлас почв Рязанской области (Atlas of Soils of the Ryazan Region). Рязань, 2006. 62 p. (In Russian).

3. State report "On the state and on the protection of the environment of the Russian Federation in 2015". http://www.mnr.gov.ru/gosdoklad-eco-2015/

4. Гусева Т.М. Экологическая оценка загрязнения ландшафтов тяжелыми металлами на при мере модельного ландшафта левобережья Окского бассейна (Environmental assessment of pollution of landscapes with heavy metals on the model landscape of the left bank of the Oka basin). Candidate of Agricultural Sciences thesis. Рязань, 2001. - 167 p. (In Russian).

5. Касимов Н.С., Власов Д.В. Кларки химических элементов как эталоны сравнения в экогеохимии (Clarks of chemical elements as comparison standards in ecogeochemistry). Mos. Univ. Journ. 5, vol 2, 2015, pp.7-17. (In Russian).

6. Кривцов В.А. и др. Природный потенциал ландшафтов Рязанской области (Natural potential of landscapes of the Ryazan region). Рязань: Ryaz. St. Univ, 2011. 768 p.

7. A. Gorobets, Eco-centric policy for sustainable development. Journal of Cleaner Production, vol. 64, 2014. pp. 654-655.

8. Swinnen J., Van Herck K., Vranken L. Land Market Regulations in Europe. LICOS Discussion Paper Series, 354, 2014, pp. 1-31.

9. Glenn W. Suter II. Ecological Risk Assessment, Second Edition. CRC Press, 2016. 680 p. 